\title{
Effects of Nutrient, $\mathrm{NaCl}$ and Heat Stresses on the Major Cation Contents in Tomato Seedlings
}

\author{
Yuelin ZHU and Tadashi ITO \\ Faculty of Horticulture, Chiba University, Matsudo 271-8510, Japan
}

(Received April 3, 2000)

\begin{abstract}
The effects of nutrient, $\mathrm{NaCl}$ and heat stresses on the major cation $(\mathrm{K}, \mathrm{Ca}$ and $\mathrm{Mg}$ ) contents were studied in tomato (Lycopersicon esculentum Mill. cv. House Momotaro) seedlings. The purpose of the present work was to explore the similarity of cation responses under the above-mentioned stress conditions. Nutrient stress was applied by splitting the seedling roots into two parts, one of which was grown in 1/2 strength Enshi standard nutrient solution (ESNS) and the other was immersed in tap water. $\mathrm{NaCl}$ stress was conducted by treating the seedlings with $1 / 4$ strength ESNS containing $150 \mathrm{~mm} \mathrm{NaCl}$ for 1 week (1/4 strength ESNS without $\mathrm{NaCl}$ as control). Heat stress was imposed by treating the seedlings at light $38^{\circ} \mathrm{C}$ and dark $33^{\circ} \mathrm{C}$ for 1 week (light $25^{\circ} \mathrm{C}$ and dark $20^{\circ} \mathrm{C}$ as control). It was found that leaf $\mathrm{K}$ content was significantly decreased under both nutrient and $\mathrm{NaCl}$ stresses, while it was significantly increased under heat stress. Leaf Ca content was unaffected under both nutrient and $\mathrm{NaCl}$ stresses, but significantly increased under heat stress. Leaf $\mathrm{Mg}$ content was significantly increased under nutrient, $\mathrm{NaCl}$ and heat stresses.
\end{abstract}

Keywords : tomato, hydroponics, split-root system, nutrient stress, $\mathrm{Mg}$ accumulation

\section{INTRODUCTION}

Cation contents of tomato plants are affected by several environmental stresses, such as salinity stress (Mitchell et al., 1991 ; Atta-Aly et al., 1992 ; Bolarín et al., 1995), heat stress (Choluj, 1996), and nutrient stress (Sonneveld and Voogt, 1991). In a previous study, we found that nutrient stress by split-root system significantly increased leaf $\mathrm{Mg}$ content (Zhu and Ito, 2000). Whether this phenomenon also occurs under $\mathrm{NaCl}$ and heat stresses remains unknown.

$\mathrm{K}$ content in tomato tissues, expressed on a dry weight basis, declines as the Na-salinity in the root media is increased (Pérez-Alfocea et al., 1996; Song and Fujiyama, 1996), while Ca content remains unaffected in tomato leaves and stems (Carvajal et al., 1999). Although salinity studies have analyzed plant tissues for $\mathrm{Mg}$ content, most of the salinity-nutrition studies have directed little attention to Mg nutrition as affected by salinity. Faiz et al. (1994) reported that $\mathrm{Mg}$ content in tomato shoots was increased with increasing salinity, but in their saline treatment, $\mathrm{NaCl}, \mathrm{MgCl}_{2}$ and $\mathrm{MgSO}_{4}$ were included.

Under high root zone temperature, $\mathrm{K}$ content was increased, Ca content was decreased and $\mathrm{Mg}$ content was unaffected in tomato leaves (Nkansah and Ito, 1995). Heat stress, however, increased Ca translocation into tomato fruits (Starck et al., 1994). The objective of

Corresponding author : Tadashi Ito, fax : +81-47-364-2237, e-mail : itot @ midori-h.chiba-u.ac.jp 
this paper is to explore the similarity of cation responses in tomato plants under nutrient, $\mathrm{NaCl}$ and heat stresses.

\section{MATERIALS AND METHODS}

Plant material. Seedlings of Lycopersicon esculentum Mill. cv. House Momotaro (Takii \& Co., Ltd., Japan) were used in this study.

Nutrient stress experiments. Two hydroponic culture experiments were carried out in the greenhouse of the Faculty of Horticulture, Chiba University.

Experiment 1 was conducted in winter of 1997 . The seedling raising method, the design of treatments, and the management of nutrient solution during seedling raising and treatment periods were the same as described in our previous report (Zhu and Ito, 2000). On October 30 , seeds were sown in rice husk charcoal. Seven days after sowing, seedlings with fully expanded cotyledons were transplanted to polyurethane substrates. On November 28 , seedlings with four expanded leaves were transplanted into 1/2000 a Wagner's pots, with one seedling in a pot. Plants were aerated by air bubbles. Two treatments were designed as follows. 1) All roots of the seedling were grown in $1 / 2$ strength Enshi standard nutrient solution (EC $=1.46 \mathrm{dS} \cdot \mathrm{m}^{-1}$, ESNS). 2) The roots of the seedling were evenly split into two parts, and one part was grown in $1 / 2$ strength ESNS and the other in tap water $(\mathrm{EC}=0.36 \mathrm{dS}$ $\mathrm{m}^{-1}$ ). Five plants were grown in each treatment. On December 30 , when the first truss flowered, the plants were harvested.

The same experiment was repeated in spring of 1998 (Experiment 2). The plant material and experimental methods were the same as those for Experiment 1, except for leaf sampling (see below). Seeds were sown on April 6 and seedlings were transferred to polyurethane substrates on April 17. On May 2 seedlings with four expanded leaves were transplanted into Wagner's pots as described above. On May 25, when the first truss flowered, the plants were harvested.

The daily maximum and minimum air temperatures were recorded with a maximumminimum thermometer, and nutrient solution temperature was recorded at $9: 00$ A.M. throughout this experiment. During 1997 winter cultivation, the daily maximum and minimum air temperatures ranged from 20 to $29^{\circ} \mathrm{C}$ and 10 to $15^{\circ} \mathrm{C}$ respectively, and nutrient solution temperature varied from 14 to $20^{\circ} \mathrm{C}$. There were $9 \mathrm{~d}$ with minimum temperature of $10^{\circ} \mathrm{C}$. During 1998 spring cultivation, the daily maximum and minimum air temperatures ranged from 18 to $34^{\circ} \mathrm{C}$ and 12 to $20^{\circ} \mathrm{C}$ respectively, and nutrient solution temperature fluctuated between 15 and $25^{\circ} \mathrm{C}$. There were $5 \mathrm{~d}$ with minimum temperature of $12^{\circ} \mathrm{C}$. The overall temperatures in winter cultivation were lower than those in spring cultivation.

$\mathrm{NaCl}$ stress experiment. On November 15, 1999, seeds were sown in growing medium Serubaido (Sumirin Agro-Products Co., Ltd., Japan). Three weeks after sowing, seedlings with 2 leaves were transferred into plastic pots $(10.5 \mathrm{~cm}$ in diameter), filled with growing medium Tsuchitaro (Sumirin Agro-Products Co., Ltd., Japan). The seedlings were raised in a plastic greenhouse. On January 25, 2000, when seedlings reached 8 leaves, $\mathrm{NaCl}$ treatment was started. Five seedlings were put into each plastic container $(45 \times 30 \times 11 \mathrm{~cm})$, two containers were used, one for $\mathrm{NaCl}$ treatment, the other for control. $\mathrm{NaCl}$ treatment was applied by adding $1 / 4$ strength ESNS containing $150 \mathrm{mM} \mathrm{NaCl}$ into the container until reaching a depth of $2 \mathrm{~cm}$. As control, only 1/4 strength ESNS was added into the other container. Both containers were placed in the same growth chamber. The nutrient solution in the containers was renewed every $2 \mathrm{~d}$ after the beginning of treatment. The environmental conditions of the growth chamber were set as follows: temperature was kept at 25 and $15^{\circ} \mathrm{C}$ during light and dark periods of $12 \mathrm{~h}$ each respectively, with light source of HPS lamps of 
PPFD $400 \mu \mathrm{mol} \mathrm{m}^{-2} \mathrm{~s}^{-1}$, relative humidity at $60 \%$, and $\mathrm{CO}_{2}$ concentration at $400 \mathrm{ppm}$. After 1 week of treatment, the plants were harvested.

Heat stress experiment. On October 27, 1999, seeds were sown in peat moss. Two weeks after sowing, seedlings with two leaves were transferred into plastic pots $(5 \mathrm{~cm}$ in diameter), filled with rice husk charcoal. The pots were put into a plastic tank $(90 \times 60 \times 20$ $\mathrm{cm}$ ), into which $1 / 8$ strength ESNS was added. The management of nutrient solution was the same as described in nutrient stress experiments. On December 5, when seedlings reached 6 leaves, the plants were exposed to heat stress treatment. The pots were put into plastic containers with four pots in each container, into which $1 / 4$ strength $\left(\mathrm{EC}=0.95 \mathrm{dS} \cdot \mathrm{m}^{-1}\right) \mathrm{ESNS}$ was added until reaching a depth of $2 \mathrm{~cm}$. For one treatment, two containers were put into each growth chamber. Two growth chambers were used, one for heat stress treatment (38 and $33^{\circ} \mathrm{C}$ during light and dark periods of $12 \mathrm{~h}$ each respectively) and the other for control ( 25 and $20^{\circ} \mathrm{C}$ during light and dark periods of $12 \mathrm{~h}$ each respectively). The plastic containers, the renewal of nutrient solution, and the environmental conditions of the growth chambers were the same as described in $\mathrm{NaCl}$ stress experiment, except for temperature. After 1 week of treatment, the plants were harvested.

Sampling and mineral content analysis. In nutrient stress Experiment 1, plants were divided into root, stem, lower 3 leaves, middle 3 leaves, and upper 3 leaves. In nutrient stress Experiment 2, plants were divided into root, stem, lower 4 leaves, middle 4 leaves, and upper 4 leaves. In heat and $\mathrm{NaCl}$ stress experiments, only the shoots were sampled. Shoots were divided into two parts, leaflets and stems with petioles. Samples of roots, leaves, and stems (or stems with petioles) were dried in an oven at $65^{\circ} \mathrm{C}$ for 1 week. The dried samples were milled and digested with $\mathrm{H}_{2} \mathrm{SO}_{4}$-salicylic- $\mathrm{H}_{2} \mathrm{O}_{2}$ in flasks for mineral content determination (Walinga et al., 1995). Cations were determined by an atomic absorption spectrophotometer. Data were subjected to analysis of variance and the means were separated at $p<0.05$ by Duncan's new multiple range test.

\section{RESULTS}

\section{$\mathrm{K}, \mathrm{Ca}$ and $\mathrm{Mg}$ contents under nutrient stress}

Table 1 shows the effects of nutrient stress by split-root system on $\mathrm{K}$ contents of leaves and stems. In both winter and spring cultivation, $\mathrm{K}$ content was significantly decreased in lower leaves under nutrient stress. However, no significant difference in $\mathrm{K}$ contents was found in middle leaves, upper leaves and stems. In both winter and spring experiments, no significant difference in $\mathrm{Ca}$ contents of leaves and stems was observed between nutrient stress treatment

Table 1 Effects of nutrient stress by split-root system on potassium contents $\left(\mathrm{mg} \cdot \mathrm{g}^{-1} \mathrm{DW}\right)$ of tomato leaves and stems.

\begin{tabular}{|c|c|c|c|c|}
\hline \multirow{2}{*}{ Treatment } & \multicolumn{3}{|c|}{ Leaves } & \multirow{2}{*}{ Stems } \\
\hline & Lower & Middle & Upper & \\
\hline \multicolumn{5}{|l|}{1997 winter cultivation } \\
\hline 1/2 ESNS + water & $60.2 b^{z}$ & $71.5 \mathrm{a}$ & $70.7 \mathrm{a}$ & $116.8 \mathrm{a}$ \\
\hline 1/2 ESNS (control) & $70.8 \mathrm{a}$ & $76.9 \mathrm{a}$ & $75.8 \mathrm{a}$ & $125.0 \mathrm{a}$ \\
\hline \multicolumn{5}{|l|}{1998 spring cultivation } \\
\hline 1/2 ESNS + water & $62.7 b^{z}$ & $74.5 \mathrm{a}$ & $70.5 \mathrm{a}$ & $113.0 \mathrm{a}$ \\
\hline $1 / 2$ ESNS (control) & $71.5 \mathrm{a}$ & $80.2 \mathrm{a}$ & $73.9 \mathrm{a}$ & $109.2 \mathrm{a}$ \\
\hline
\end{tabular}


and the control (data not shown).

Table 2 presents the effects of nutrient stress by split-root system on $\mathrm{Mg}$ contents of leaves and stems. In stems, nutrient stress did not significantly change $\mathrm{Mg}$ contents in both winter and spring cultivation. In winter cultivation, nutrient stress significantly increased $\mathrm{Mg}$ contents in all parts of leaves. In spring cultivation, however, this was observed only in middle leaves.

Effects of nutrient stress by split-root system on $\mathrm{K}, \mathrm{Ca}$ and $\mathrm{Mg}$ contents of roots are given in Table 3. The pattern of $\mathrm{K}, \mathrm{Ca}$ and $\mathrm{Mg}$ accumulation of roots in winter cultivation was similar to that in spring cultivation. $K$ content of split roots either grown in $1 / 2$ strength ESNS or immersed in tap water was significantly lower than that of the control. Ca content of split roots immersed in tap water was significantly lower than that of the control. However, this was not found in the split roots grown in $1 / 2$ strength ESNS. The highest $\mathrm{Mg}$ content was observed in the split roots immersed in tap water.

\section{$\mathrm{K}, \mathrm{Ca}, \mathrm{Mg}$ and $\mathrm{Na}$ contents under $\mathrm{NaCl}$ stress}

Table 4 presents the effects of $\mathrm{NaCl}$ stress on $\mathrm{K}, \mathrm{Ca}, \mathrm{Mg}$ and $\mathrm{Na}$ contents of different parts of shoots. $\mathrm{K}$ contents of both leaflets and stems with petioles of $\mathrm{NaCl}$ treatment were significantly lower than those of the control. No significant differences in Ca contents of both leaflets and stems with petioles were found between $\mathrm{NaCl}$ treatment and the control. $\mathrm{Mg}$ content in leaflets of $\mathrm{NaCl}$ treatment was significantly higher than that of the control, showing no difference in stems with petioles. Na contents in both leaflets and stems with petioles of $\mathrm{NaCl}$ treatment were significantly higher than those of the control.

Table 2 Effects of nutrient stress by split-root system on $\mathrm{Mg}$ contents $\left(\mathrm{mg} \cdot \mathrm{g}^{-1} \mathrm{DW}\right)$ of tomato leaves and stems.

\begin{tabular}{crrrr}
\hline \multirow{2}{*}{ Treatment } & \multicolumn{3}{c}{ Leaves } & \multirow{2}{*}{ Stems } \\
\cline { 2 - 4 } & Lower & Middle & Upper & \\
\hline 1997 winter cultivation & & & & \\
1/2 ESNS + water & $15.2 \mathrm{a}^{2}$ & $12.5 \mathrm{a}$ & $9.5 \mathrm{a}$ & $6.3 \mathrm{a}$ \\
1/2 ESNS (control) & $11.8 \mathrm{~b}$ & $9.2 \mathrm{~b}$ & $7.7 \mathrm{~b}$ & $4.6 \mathrm{a}$ \\
1998 spring cultivation & & & & \\
1/2 ESNS+ water & $17.9 \mathrm{a}^{2}$ & $13.0 \mathrm{a}$ & $8.3 \mathrm{a}$ & $6.3 \mathrm{a}$ \\
1/2 ESNS (control) & $15.3 \mathrm{a}$ & $9.5 \mathrm{~b}$ & $6.7 \mathrm{a}$ & $5.4 \mathrm{a}$ \\
\hline
\end{tabular}

${ }^{\text {z,y }}$ See Table 1 .

Table 3 Effects of nutrient stress by split-root system on $\mathrm{K}, \mathrm{Ca}$ and $\mathrm{Mg}$ contents $\left(\mathrm{mg} \cdot \mathrm{g}^{-1} \mathrm{DW}\right)$ of tomato roots.

\begin{tabular}{ccrrr}
\hline Treatment & Sampled part $^{\mathrm{x}}$ & $\mathrm{K}$ & $\mathrm{Ca}$ & $\mathrm{Mg}$ \\
\hline 1997 winter cultivation & & & & \\
1/2 ESNS ${ }^{\mathrm{y}}+$ water & $\mathrm{N}$ & $104.4 \mathrm{~b}^{z}$ & $9.3 \mathrm{a}$ & $5.3 \mathrm{~b}$ \\
& $\mathrm{~W}$ & $56.0 \mathrm{c}$ & $2.5 \mathrm{~b}$ & $10.6 \mathrm{a}$ \\
1/2 ESNS (control) & $\mathrm{N}$ & $126.6 \mathrm{a}$ & $9.2 \mathrm{a}$ & $4.5 \mathrm{~b}$ \\
1998 spring cultivation & & & & \\
1/2 ESNS+ water & $\mathrm{N}$ & $77.6 \mathrm{~b}^{z}$ & $5.2 \mathrm{a}$ & $9.2 \mathrm{~b}$ \\
& $\mathrm{~W}$ & $34.6 \mathrm{c}$ & $2.4 \mathrm{~b}$ & $18.2 \mathrm{a}$ \\
1/2 ESNS (control) & $\mathrm{N}$ & $87.9 \mathrm{a}$ & $6.1 \mathrm{a}$ & $9.0 \mathrm{~b}$ \\
\hline
\end{tabular}

${ }^{2, y}$ See Table 1.

${ }^{x}$ For the treatment of $1 / 2$ ESNS + water, there are two root samples, one of which is from nutrient solution $(\mathrm{N})$, the other from tap water $(\mathrm{W})$. 
Table 4 Effects of $\mathrm{NaCl}$ stress on $\mathrm{K}, \mathrm{Ca}, \mathrm{Mg}$ and $\mathrm{Na}$ contents $\left(\mathrm{mg} \cdot \mathrm{g}^{-1} \mathrm{DW}\right)$ of different parts of shoots in tomato seedlings.

\begin{tabular}{|c|c|c|c|c|c|c|c|c|}
\hline \multirow{2}{*}{ Treatment } & \multicolumn{2}{|c|}{ K } & \multicolumn{2}{|c|}{$\mathrm{Ca}$} & \multicolumn{2}{|c|}{$\mathrm{Mg}$} & \multicolumn{2}{|c|}{$\mathrm{Na}$} \\
\hline & $L^{\mathrm{y}}$ & $\mathrm{S}+\mathrm{P}^{\mathrm{y}}$ & $\mathrm{L}$ & $\mathrm{S}+\mathrm{P}$ & $\mathrm{L}$ & $\mathrm{S}+\mathrm{P}$ & $\mathrm{L}$ & $\mathrm{S}+\mathrm{P}$ \\
\hline $\mathrm{NaCl}$ & $25.7 b^{z}$ & $51.1 \mathrm{~b}$ & $7.9 \mathrm{a}$ & $3.6 \mathrm{a}$ & $11.6 \mathrm{a}$ & $10.1 \mathrm{a}$ & $94.8 \mathrm{a}$ & $74.1 \mathrm{a}$ \\
\hline Control & $29.2 \mathrm{a}$ & $68.9 \mathrm{a}$ & $8.0 \mathrm{a}$ & $4.1 \mathrm{a}$ & $10.4 \mathrm{~b}$ & $9.7 \mathrm{a}$ & $3.2 \mathrm{~b}$ & $7.2 \mathrm{~b}$ \\
\hline
\end{tabular}

${ }^{2}$ See Table 1.

${ }^{\mathrm{y}} \mathrm{L}$ stands for leaflets, $\mathrm{S}+\mathrm{P}$ for stems with petioles.

Table 5 Effects of heat stress on $\mathrm{K}, \mathrm{Ca}$ and $\mathrm{Mg}$ contents $\left(\mathrm{mg} \cdot \mathrm{g}^{-1} \mathrm{DW}\right)$ of different parts of shoots in tomato seedlings.

\begin{tabular}{|c|c|c|c|c|c|c|}
\hline \multirow{2}{*}{ Treatment } & \multicolumn{2}{|c|}{$\mathrm{K}$} & \multicolumn{2}{|c|}{$\mathrm{Ca}$} & \multicolumn{2}{|c|}{$\mathrm{Mg}$} \\
\hline & $\mathrm{L}^{\mathrm{y}}$ & $\mathrm{S}+\mathrm{P}^{\mathrm{y}}$ & $\mathrm{L}$ & $\mathrm{S}+\mathrm{P}$ & $\mathrm{L}$ & $\mathrm{S}+\mathrm{P}$ \\
\hline Heat & $39.6 \mathrm{a}^{\mathrm{z}}$ & $106.4 \mathrm{a}$ & $9.1 \mathrm{a}$ & $4.5 \mathrm{a}$ & $11.7 \mathrm{a}$ & $5.9 \mathrm{a}$ \\
\hline Control & $28.6 \mathrm{~b}$ & $107.7 \mathrm{a}$ & $7.1 \mathrm{~b}$ & $4.1 \mathrm{a}$ & $8.7 \mathrm{~b}$ & $5.6 \mathrm{a}$ \\
\hline
\end{tabular}

${ }^{z}$ See Table 1.

${ }^{\mathrm{y}}$ See Table 4.

\section{$\mathrm{K}, \mathrm{Ca}$ and $\mathrm{Mg}$ contents under heat stress}

Table 5 shows the effects of heat stress on $\mathrm{K}, \mathrm{Ca}$ and $\mathrm{Mg}$ contents of different parts of shoots. In leaflets, $\mathrm{K}, \mathrm{Ca}$ and $\mathrm{Mg}$ contents of heat stress treatment were significantly higher than those of the control. In stems with petioles, no significant differences in $\mathrm{K}, \mathrm{Ca}$ and $\mathrm{Mg}$ contents were found between heat stress treatment and the control.

\section{DISCUSSION}

$\mathrm{Mg}$ content of leaves increased under nutrient stress (Table 2), $\mathrm{NaCl}$ stress (Table 4), and heat stress (Table 5). When the split roots were immersed in tap water, $\mathrm{K}$ and $\mathrm{Ca}$ contents of roots were significantly reduced, but $\mathrm{Mg}$ content significantly increased (Table 3). Why was $\mathrm{Mg}$ content significantly increased? When tomato plants were subjected to nutrient stress, fruit vascular development was significantly promoted (Sanders et al., 1996). Smith (1973) found that in K-deficient barley leaves, putrescine was 13.3-fold greater than the control. This was confirmed in the leaves of barley, radish, pea, bean and spinach plants (Basso and Smith, 1974). Under nutrient stress, polyamine accumulation and ethylene evolution were enhanced in tomato leaves (Corey and Barker, 1989; Feng and Barker, 1993). Espartero et al. (1994) reported that under $\mathrm{NaCl}$ stress, SAMl gene (encoding S-adenosyl-L-methionine, SAM synthetase) was expressed. SAM synthetase is required in lignifying tissue and vascular development (Espartero et al., 1994). SAM synthetase catalyzes the conversion of methionine and ATP to SAM. SAM is a precursor in polyamine and ethylene biosynthesis (Yang and Hoffman, 1984 ; Corey and Barker, 1989). It has been found that SAM synthetase requires an unusually high concentration of $\mathrm{Mg}^{2+}$ for optimal activity (Mudd and Cantoni, 1958; Markham et al., 1983). We postulate that the increased Mg contents in roots and leaves in the present work might be related to the increased activity of some enzymes.

Under nutrient stress by split-root method, $\mathrm{K}$ contents of lower leaves (Table 1) and roots (Table 3) were significantly reduced. Under $\mathrm{NaCl}$ stress, $\mathrm{Na}$ contents in both leaflets and stems with petioles were significantly increased, while $\mathrm{K}$ contents in both leaflets and stems with petioles were significantly declined (Table 4). There is competition with $\mathrm{K}$ uptake by 
other cations under stress conditions (Gadallah, 1996; Okubo and Utsunomiya, 1996). The reduction of $\mathrm{K}$ content under either nutrient stress or $\mathrm{NaCl}$ stress in the present work might result from $\mathrm{Mg}-\mathrm{K}$ or $\mathrm{Na}-\mathrm{K}$ antagonism

$\mathrm{Ca}$ content in leaflets was significantly increased under heat stress (Table 5), $\mathrm{Ca}$ is transported mainly through the xylem vessels and its distribution within a plant is affected by the transpiration stream and by IAA (Hanson, 1984). Although the transpiration rate of leaves was not determined in this study, high transpiration rate of leaves might occur under high temperature $\left(38^{\circ} \mathrm{C}\right)$ with plenty of water supply. The increasing of $\mathrm{Ca}$ content under heat stress might result from the high transpiration rate of leaves.

In the present investigation, leaf $\mathrm{Mg}$ content (especially in middle leaves, Table 2) of tomato seedlings was increased under nutrient stress by split-root system. This result was in agreement with our previous report (Zhu and Ito, 2000). Sonneveld and Voogt (1991) reported that $\mathrm{Ca}$ stress (deprivation) significantly increased leaf $\mathrm{Mg}$ content in rockwool grown tomato. Under $\mathrm{NaCl}$ stress, $\mathrm{K}$ content was significantly decreased, $\mathrm{Ca}$ content was unaffected, and $\mathrm{Na}$ content was significantly increased in shoots (Table 4). This result coincided with reports of other researchers (Pérez-Alfocea et al., 1996; Carvajal et al., 1999). Leaf Mg content was significantly increased under $\mathrm{NaCl}$ stress (Table 4). Although Faiz et al. (1994) reported that $\mathrm{Mg}$ content in tomato shoots was increased with increasing salinity, but in their saline treatment, $\mathrm{NaCl}, \mathrm{MgCl}_{2}$ and $\mathrm{MgSO}_{4}$ were included. Therefore, it was difficult to distinguish the effect of $\mathrm{NaCl}$ from that of $\mathrm{MgCl}_{2}$ and $\mathrm{MgSO}_{4}$ on the elevation of shoot $\mathrm{Mg}$ content. Under heat stress, leaf $\mathrm{K}, \mathrm{Ca}$ and $\mathrm{Mg}$ contents were significantly increased (Table 5). Nkansah and Ito (1995) reported that under high root zone temperature, K content was increased, $\mathrm{Ca}$ content was decreased, and $\mathrm{Mg}$ content was unaffected in tomato leaves. Our result was partly different from that of Nkansah and Ito (1995). This might arise from different tomato cultivars and different experimental methods.

In conclusion, leaf $\mathrm{Mg}$ content was significantly increased under nutrient, $\mathrm{NaCl}$ and heat stresses. Leaf $\mathrm{K}$ content, however, was decreased under both nutrient and $\mathrm{NaCl}$ stresses, while it was increased under heat stress. Leaf Ca content was unaffected under both nutrient and $\mathrm{NaCl}$ stresses, but significantly increased under heat stress. These results demonstrated that the pattern of $\mathrm{Mg}$ response in leaves of tomato seedlings was very similar, while that of $\mathrm{K}$ and Ca was different under the stress conditions conducted in the present work.

The scholarship from the Ministry of Education, Science, Sports and Culture of Japan to Yuelin Zhu is greatly appreciated.

\section{REFERENCES}

Atta-Aly, M. A., Saltveit, M. E., El-Beltagy, A. S. 1992. Effect of salt stress on the vegetative growth and development of tomato plants. Acta Hortic. 323 : 401-410.

Basso, L. C., Smith, T. A. 1974. Effect of mineral deficiency on amine formation in higher plants. Phytochemistry $13: 875-883$.

Bolarí/n, M. C., Santa-Cruz, A., Cayuela, E., Pérez-Alfocea, F. 1995. Short-term solute changes in leaves and roots of cultivated and wild tomato seedlings under salinity. J. Plant Physiol. 147: 463468.

Carvajal, M., Martínez, V., Cerdá, A. 1999. Influence of magnesium and salinity on tomato plants grown in hydroponic culture. J. Plant Nutr. 22 : 177-190.

Choluj, D. 1996. Effects of heat stress on calcium and phosphorus uptake and distribution in tomato cuttings with different potassium supply. Acta Physiol. Plant. 18 : 85-90.

Corey, K. A., Barker, A. V. 1989. Ethylene evolution and polyamine accumulation by tomato subjected 
to interactive stresses of ammonium toxicity and potassium deficiency. J. Am. Soc. Hortic. Sci. 114 : 651-655.

Espartero, J., Pintor-Toro, J. A., Pardo, J. M. 1994. Differential accumulation of S-adenosylmethionine synthetase transcripts in response to salt stress. Plant Mol. Biol. 25 : 217-227.

Faiz, S. M. A., Ullah, S. M., Hussain, A. K. M. A., Kamal, A. T. M. M., Ardus-Satter. $1994 . \quad$ Yield, mineral contents and quality of tomato (Lycopersicon esculentum) under salt stress in a saline soil. Current Agric. 18 : 9-12.

Feng, J., Barker, A. V. 1993. Polyamine concentration and ethylene evolution in tomato plants under nutritional stress. HortScience 28 : 109-110.

Gadallah, M. A. A. 1996. Abscisic acid, temperature and salinity interactions on growth and some mineral elements in Carthamus plants. Plant Growth Regul. 20 : 225-236.

Hanson, J. B. 1984. The functions of calcium in plant nutrition. Adv. Plant Nutr. 1: 149-208.

Ikeda, H. 1998. Types and the management of nutrient solution. In "Handbook of Protective Horticulture" (ed. By Japanese Association of Protective Horticulture), Ed. 4. (Japanese text) Information Center for Horticulture, Tokyo, p 420-424.

Markham, G. D., Hafner, E. W., Tabor, C. W., Tabor, H. 1983. S-Adenosylmethionine synthetase (methionine adenosyltransferase) (Escherichia coli). Methods Enzymol. 94 : 219-222.

Mitchell, J. P., Shennan, C., Grattan, S. R., May, D. M. 1991. Tomato fruit yields and quality under water deficit and salinity. J. Am. Soc. Hortic. Sci. $116: 215-221$.

Mudd, S. H., Cantoni, G. L. 1958. Activation of methionine for transmethylation. III. The methionineactivating enzyme of Bakers' yeast. J. Biol. Chem. 231 : 481-492.

Nkansah, G. O., Ito, T. 1995. Comparison of mineral absorption and nutrient composition of heattolerant and non heat-tolerant tomato plants at different root-zone temperatures. J. Hortic. Sci. 70 : 453-460.

Okubo, M., Utsunomiya, N. 1996. Effects of sodium chloride on growth, gas exchange and ion concentration in latex of fig (Ficus carica L.). Environ. Control in Biol. 34 : 259-265.

Pérez-Alfocea, F., Balibrea, M. E., Santa-Cruz, A., Estañ, M. T. 1996. Agronomical and physiological characterization of salinity tolerance in a commercial tomato hybrid. Plant Soil 180: 251-257.

Sanders, D. C., Cure, J. D., Deyton, P. M., Gardner, R. G. 1996. Assessing vascularization response of three tomato (Lycopersicon esculentum Mill.) cultivars to soil type, nutrient stress and water stress. HortTechnology 6 : 405-408.

Smith, T. A. 1973. Amines levels in mineral-deficient Hordeum vulgare leaves. Phytochemistry 12 : 2093-2100.

Song, J. Q., Fujiyama, H. 1996. Difference in response of rice and tomato subjected to sodium salinization to the addition of calcium. Soil Sci. Plant Nutr. $42: 503-510$.

Sonneveld, C., Voogt, W. 1991. Effects of Ca-stress on blossom-end rot and Mg-deficiency in rockwool grown tomato. Acta Hortic. 294 : 81-88.

Starck, Z., Siwiec, A., Chotuj, D. 1994. Distribution of calcium in tomato plants in response to heat stress and plant growth regulators. Plant Soil 167 : 143-148.

Walinga, I., van der Lee, J. J., Houba, V. J. G., van Vark, W., Novzamsky, I. 1995. Plant Analysis Manual. Kluwer Academic Publisher, Dordrecht.

Yang, S. F., Hoffman, N. E. 1984. Ethylene biosynthesis and its regulation in higher plants. Annu. Rev. Plant Physiol. 35 : 155-189.

Zhu, Y., Ito, T. 2000. Effects of nutrient stress by split-root system on the growth and major cation contents at different stages of hydroponically-grown tomato seedlings. J. Jpn. Soc. Hortic. Sci. 69(6) : in press. 


\title{
苌分・NaCl および高温ストレスがトマト苗の主要カチオン含有率におよぼす影慗
}

\author{
朱 月林・伊東 正
}

千葉大学園芸学部

養分・ $\mathrm{NaCl}$ および高温ストレス条件でトマト (Lycopersicon esculentum Mill. cv. ハウス桃太 郎) 苗の主要カチオン ( $\mathrm{K}, \mathrm{Ca}$ および $\mathrm{Mg}$ ) 含有率を調査した。本研究の目的は, 上記のストレス 条件で, カチオン感応の類似性を検討することであった. 養分ストレス区として, トマト苗の根を 二つに分け, 一つは園試処方の $1 / 2$ 濃度に, もう一つは水道水にそれぞれ浸漬し, その対照区とし て,トマト苗を園試処方の $1 / 2$ 濃度で水耕した. $\mathrm{NaCl}$ ストレス区として, トマト苗を $150 \mathrm{~mm} \mathrm{NaCl}$ を加えた園試処方の $1 / 4$ 濃度で 1 週間処理し, その対照区として, トマト苗を $\mathrm{NaCl}$ 無添加の同濃 度培養液で生長させた. 高温ストレス区として, トマト苗を明期 $38^{\circ} \mathrm{C} \cdot$ 暗期 $33^{\circ} \mathrm{C} て ゙ 1$ 週間処理し, その対照区として, トマト苗を明期 $25^{\circ} \mathrm{C} \cdot$ 暗期 $20^{\circ} \mathrm{C}$ で生長させた。 葉の $\mathrm{K}$ 含有率は, 養分・ $\mathrm{NaCl}$ ストレス区で, 有意に低下し, 高温ストレス区で, 有意に増加した. 葉の $\mathrm{Ca}$ 含有率は, 責分・ $\mathrm{NaCl}$ ストレス区で, 対照区と有意差が認められず, 高温ストレス区で, 有意に増加した. 葉の $\mathrm{Mg}$ 含有 率は, 養分・ $\mathrm{NaCl}$ および高温ストレス区で, 有意に増加した. 